\title{
Traditional Ukrainian Folk Beliefs about Death and the Afterlife (1)
}

\author{
Svitlana Kukharenko \\ Modern Languages and Cultural Studies \\ University of Alberta \\ Edmonton, AB, Canada
}

\section{Abstract}

In contemporary Ukraine, there exist various memorials that mark places of tragic death. These can be found on any road in large numbers. They can also be found elsewhere, including in city centers. To understand this phenomenon it is necessary to examine Ukrainian attitudes towards death. The most complete descriptions of folk beliefs about death date from the late $19^{\text {th }}$ century. In Ukrainian culture death was viewed as a natural and integral part of human life and the dead could communicate with the living and vice versa. There were considered to be two types of death. "Good death" was something to strive for and, in a way, welcome and the preparation of the body and its burial followed prescribed rituals. A "bad death" was that of a suicide, a murder victim, or a person killed in an accident. Such people were not given the normal funerary rites and they were usually buried by road sides, not in the cemetery. Their souls were believed to wander the earth and could harm the living. In most cases the site of a "bad death" would be memorialized and this tradition is preserved in present day Ukraine. There are also cases of ambiguous death, such as the death of small children or women who die in childbirth. This article surveys traditional death beliefs and practices to provide information useful in understanding Ukrainian culture.

A monument to a young man, a law student at Kyiv State University who died at the young age of twenty-one, stands outside the window of a fancy electronics store in Kyiv. The monument has been there a long time: the date of death is 1996. Yet no one considers removing this memorial, even though it provides somewhat of a physical impediment to people entering the store. The young man was murdered on the steps of the store and the very visible reminder to that tragedy which the monument provides might well discourage customers from patronizing the establishment. Yet when this author asked the store's manager about the possibility of removing the memorial, he seemed puzzled. How could one contemplate such a thing? The monument was there when he became 
manager and the idea of moving to improve business had never occurred to him. Ukrainians have an understanding of death that differs from that found in North America. To comprehend Ukrainian culture, whether for economic purposes or for any other reason, it is necessary to examine beliefs about death and the afterlife.

Death and Its Manifestations

Death is not a mere biological fact. It is also a complex of beliefs and activities immanent to a certain culture. Furthermore, studying "normal" or natural death and funerary practices related to it without considering abnormal, "bad" (i.e., tragic and unexpected), death and beliefs surrounding such death would be superficial. Death provides a context for the expression of cultural values: how people react to death, especially unanticipated death, reveals much about how they view life. In contemporary Ukraine, there exist various memorials that mark places of tragic death and can be found on any road in huge numbers. Memorials also appear in towns and cities; the monument described at the beginning of this paper is typical rather than unique. In short, memorials mark any and all locations where a person died unexpectedly. What is expressed through these memorials are traditional beliefs about "bad" death, its danger for those who met an untimely end, and for the living. In this article I present a range of traditional beliefs surrounding both types of death that are important to many Ukrainians to this day.

Death was not a taboo topic in Ukrainian culture; on the contrary, it was viewed as a natural and integral part of human life. A riddle: Од Бога менше, а од царя старше [(Whose authority is) lower than God's but higher than the Tsar's?], implied "death" as an answer [Manzhura 1890: 174] and pointed to the "democratic" nature of death in people's eyes: it did not differentiate between the poor and rich, the noble and the peasant. Numerous proverbs and sayings about death presented it as a natural event that one had to prepare for: "Смерть - неминущая дорога [Death is an inescapable path] [Nomys 1985[1864]: 158]; "Крути-не верти, а не втечеш від смерті [Either this way or that, you cannot escape death]" [Bin'kovskii 1896: 236]; “Думки за горами, а смерть за плечами [One's] thoughts are over the mountains, and [one's] death is behind [one's] shoulders]" [Hnatiuk 1912: xxxviii].

Nevertheless, there were numerous euphemisms to avoid mention of death and funerals: "Не захотів більше хліба їсти [(The person) did not want to eat bread any longer (i.e., the person died)]" [Bin'kovskii 1896: 
238]; "Пішов у далеку путь [(The person) has set off on a long journey (i.e., the person died)]" [Kotliarevskii 1891: 219]; "Посадити калину [To plant a viburnum tree (for someone) (i.e., to bury that person)] [ibid.: 250]; З'іхав 3 села [He has moved out of the village]" [Nomys 1985[1864]: 265].

According to traditional Ukrainian folk beliefs, life did not end at death, but continued, with death being just another form of existence. Death was often perceived as a long sleep, so people compared one to the other. "[The person] sleeps like the dead" meant that a person slept so soundly, nothing could awake her/him. "[The person] has fallen into an eternal sleep" meant a person had died. Generally, images of death and the afterlife were indirectly presented in lore as proverbs, sayings, omens, personal narratives, legends, and even children's games in which death was a central element or character and in which the folk understanding of a soul and its destiny was expressed.

It appears from ethnographic descriptions of the nineteenth and early-twentieth centuries that an animistic concept of death prevailed in Ukrainian beliefs. People imagined death to be an anthropomorphic being. They often described it as an ugly, crooked old woman in white or black baggy clothes [Manzhura 1890: 63; Hnatiuk 1904: 114-115] or a human skeleton with a scythe visiting a house where a death was about to occur [Afanas'ev 1868: 336, 361; Generozov 1883: 17], standing by the deathbed and visible only to the person about to die [Liatskii 1892: 40]. Death as an animated being was not believed to take people's lives randomly, by her own choice; instead, she was to go first to God for instructions [ibid.: 41]. Death was thought to be able to speak, so it was possible to negotiate with her. Although it was possible to dupe her and allow life to continue for at least several additional years, as in the legend about Death and the Soldier [Manzhura 1890: 61-63], Death could not be bribed if a human's appointed time to die had come.

Death, however, was also associated with dolia, or a person's destiny. Some legends portrayed Death not as a taker of life, but as a helper in life, a being who could become a sworn sister and assist in daily living [I[vanov] 1894: 154] or even help a human become wealthy [Grinchenko 1897: 89-91].

Death was frequently seen as an unclean spirit, sometimes equated with the devil. People would say, "Прийде чорт по його душу [A devil will come to take his soul]" [Liatskii 1892: 41]. Death was imagined as living in the underworld, more specifically in Hell, and her presence near a dying person was felt as extreme cold [Afanas'ev 1868: 336]. As an

FOLKLORICA 2011, Vol. XVI 
agent of the underworld, Death was thought to manifest herself through birds associated with evil - usually black or nocturnal ones with unpleasant calls, such as ravens, crows, owls, and magpies that would circle above the house of a dying or newly dead sinner [ibid.: 355].

Ukrainian culture surrounded human death with a complex of beliefs and omens - special warnings foretelling upcoming death, both one's own and someone else's. It was important to alert a person in time to let her/him prepare for death and it was customary to prepare for one's own death, not only in a spiritual sense but also in a physical way. For many, death was a comforting, long-awaited event, since they expected to reunite with deceased relatives immediately after death. Therefore, knowing the right time was important. People would pay special attention to the warning signs, such as a knock on the window at night or birdcalls [Hnatiuk 1904: 115-16], a dog howling with its face down [Afanas'ev 1868: 356], a chicken crowing like a rooster [Chubinskii 1877: 698], an icon falling off the wall or a mirror breaking [Miloradovich 1897: 7]. Even the birth of twins or triplets, because of their relative rarity, was thought to foretell the death of one of the parents, depending on the sex of the newborns [Manzhura 1890: 154].

Certain dreams were believed to predict death. Dreams were considered omens if they involved taking something from dead relatives [Liatskii 1892: 39], walking in a cemetery, or seeing a church procession [Miloradovich 1897: 7]. So, too, were dreams of bees, a monk, a loaf of bread, smoke, teeth falling out, blood [Manzhura 1890: 161], drowning in muddy water, a falling ceiling in one's home, an oven falling apart [Bin'kovskii 1896: 230], and so forth.

\section{Beliefs about Different Types of Death}

The death of a fellow villager was an event of significance which could affect the welfare of the entire community. Therefore, it was paramount to properly interpret not only the predictions of death, but also the type of death, and, accordingly, follow the rules of burial that would protect the rest of the villagers from possible danger. People distinguished between two types of death: a good one and a bad, sudden, or unnatural one. Good death was an ideal to strive for: "Only that death can be called 'human-'/ 'Christian-' like when a man peacefully died in his bed, while having prepared himself through confession and communion beforehand, and having said goodbye to all his relatives" [Bin'kovskii 1896: 236]. In addition, "the death must be 'one's own' 
(i.e., natural, easy, not violent); it must happen at 'one's own' time (i.e., at an appropriate age), in 'one's own' place and among 'one's' relatives. Furthermore, all the customs accepted in 'one's own' society should be observed during the burial" [Vinogradova 1999: 46].

"Bad death" meant the opposite and included both liuta (furious, i.e. violent or prolonged, agonizing death) and nahla (sudden, unnatural death). Prolonged and agonizing death was a sign that the person was associated with evil powers and, therefore, a grave sinner and certainly a witch, wizard, or vampire. Sudden, unnatural death included a wide range of events, such as death from a lightning strike, drowning, falling from a tree, suicide [Fischer 1921: 354], difficult childbirth [ibid.: 364], contagious disease, freezing along a road, and drunkenness [Bin'kovskii 1902: 158; Zelenin 1995[1916]: 39-40]. Folk beliefs, however, were inconsistent and controversial. For example, lightning and thunder were believed caused by Saints Elijah and Gabriel as they hunted demons. If someone was struck by lightning or affected by thunder, two explanations were typically offered: (1) The person was associated with unclean forces and doomed to Hell [Hnatiuk 1904: 3], or (2) the individual was an accidental victim, for a demon tried to hide inside him. Therefore, he died like a martyr and his soul would ascend to Heaven [Kotliarevskii 1891: 248-49; Miloradovich 1897: 171]. Babies who were stillborn, murdered by their mothers, or unbaptized at death also belonged in the "bad death" category, as did people of any age who had been doomed to Hell by a parental or religious curse [Miloradovich 1897: 171]. Their passing was believed the result of punishment by God and interference from evil spirits.

Good dead were buried after a regular church service and assumed to hold a neutral or positive attitude toward the living. Their souls left for some distant place, supposedly the land of ancestors or Heaven. They never disturbed the living; on the contrary, they guarded and helped their living relatives. Good death did not preclude contact with the living. Such contact could occur in dreams or by invitation from the living, but only during special occasions. Such visits were welcomed and viewed as prophetic.

Contrary to the good dead, those who died an unnatural death were assumed to be angry or envious. Such dead became unquiet or unclean revenants who lived close to the living and could harm them. One of their characteristics was the inability of their souls to proceed to the next world because death occurred before the appointed term allotted to every human by God [Zelenin 1995[1916]: 40]. To die a "bad death" meant to 
have neither forgiveness for one's soul, nor rest for one's remains in the other world.

Pious people feared "bad death." They prayed for themselves and close relatives to avoid such death and did whatever they could to ensure a good death. For example, people believed that fasting on the twelve special Fridays of the year would help ensure that they escape both nahla and liuta deaths [Ivanov 1907: 16-17]. Also, they fasted on Mondays, believing that Monday was the sacred day on which the world was created and that not eating on such a day would grant one a good, easy death. In the folk views, sacred Monday, also called St. Monday, was associated with the Apostle Peter who guarded the doors of Heaven and Hell and accompanied the souls of those who had near-death visions (завмерли) on the journeys that they experienced as part of their visions [I[vanov] 1894: 143-44].

\section{Beliefs Related to Regular and Special Funerals}

Upon someone's good death, the family of the deceased would call relatives and neighbors to help, and those requests were never refused. Otherwise, people believed, the dead would not share anything with them in the next world when their time came to die. Moreover, it was considered indecent and sinful to charge for such services as coffin making [Apollosov 1861: 220; Chubinskii 1877: 706; Miloradovich 1897: 168].

The clothed body of the deceased was put on a bench, with head toward the icons and legs toward the exit. The legs, hands, and often the jaw of the deceased were fastened with puty, ropes used to prevent involuntary movements during rigor mortis. People put a wax cross in the left hand of the deceased since, according to the folk belief, his right hand would be busy making a sign of the cross when he appeared before God [Chubynskii 1877: 698]. People would also place coins in the coffin to pay for the transfer over the river of the dead or to purchase a place in the cemetery [Bin'kovskii 1896: 254; Miloradovich 1897: 166]. In the coffin of a midwife [повитуха], people would put poppy seeds so that she would have gifts for all the children she helped to deliver when she met them in the next world [Ivanov 1909: 249].

When the deceased was taken outside, the pallbearers would stop at the threshold, lower the coffin and knock it on the threshold three times, allowing the deceased to say good-bye to his house [Chubinskii 1877: 708; Kaminskii 1912: 133-134]. 
At the cemetery, family members would remove the puty from the deceased, fearing that failure to do so would impair his quality of life in the other world; he would not be able to stand up and respond when the horn summoned him on Judgment Day [Ivanov 1909: 250].

After the coffin was lowered into the grave, a priest would "seal" the grave, i.e., make a sign of a cross over the four sides of the grave with a shovel [Moshkov 1902: 22]. Folk beliefs held that death stopped all of a dead person's earthly activities only if the grave was sealed; otherwise, he was able to return to the earth from the afterlife [Ivanov 1909: 248]. Church and secular authorities initially opposed this practice, but eventually incorporated it into the ritual since villagers considered sealing the essence of a funeral [Moshkov 1902: 22].

Funerals of those who died in a "bad" way differed dramatically from those of the good dead. Some of the bad dead had special funerals. For example, unbaptized or stillborn babies were most often buried under the threshold of the home so that people entering and leaving the house would essentially make the sign of the cross as they stepped over their graves. This would help to free the infants' souls [Vasil'ev 1890: 319; Kotliarevskii 1891: 33; Ivanov 1909: 247]. Sometimes these children were buried in family gardens [Vasil'ev 1890: 319] under a fruit or willow tree [Miloradovich 1897: 171] or at a crossroads [Chubinskii 1877: 713]. Parents would put candy and gingerbread [пряники] in the coffin of the child [Abramov 1907: 29]. The mother and other relatives were not to cry or lament the death, especially if the baby died unbaptized. If it was the first-born, mothers did not even go to the cemetery to bury the baby for fear that her subsequent children might also die [Apollosov 1861: 223; Lepkyi 1883: 13].

Marriage and procreation were so important for Ukrainians that those who died too early to be married were expected to do so in the other world. People used to say that "there is no place in the other world for a man who died unmarried" [Svidnyts'kyi 1861: 52]. Generally, Ukrainians believed that in the other world, as in this world, people would live in couples. Those who died young and unmarried were buried after a special ritual called весільний похорон [the wedding of the dead] [Sventsits'kyi 1912: 6, 45]. A young person's funeral typically resembled a marriage ceremony, although wedding songs were not sung [Lenchevskii 1899: 75; Moshkov 1902: 23]. For both a girl and a boy who died young, relatives baked a wedding bread, korovai, and shared it at the cemetery. People put a wedding band on the ring finger of a dead child, who would leave behind a symbolic spouse considered a 
widow/widower and an in-law to the family of the deceased [Kotliarevskii 1891: 237; Ivanov 1909: 254].

Some of the "bad" dead were denied proper funerals. This was a terrible punishment because only a proper funeral could ensure salvation of the soul. The importance of proper burial and proper commemoration can be seen in beliefs that focused on what happened in their absence. The soul of a person who was not properly buried and lamented was denied God's protection and the body of such a person could be used for evil purposes. This can be seen in the belief that a special candle capable of helping thieves avoid arrest could be made from the fat of a "sinless child who was not mourned by human tears and whose body was not buried in blessed soil according to proper funeral rites" [Lytvyniv 1900: 142-144].

Suicides were the most hated. Those who committed suicide were believed to go against God's will as the result of the devil's seduction and therefore they were sinners who could not be buried as Christians in a cemetery. Their presence, it was thought, would desecrate the soil and anger other, "clean" dead [Zelenin 1995[1916]: 92]. Thus suicides were usually buried along roads or at crossroads, [Chubinskii 1877: 712; Kotliarevskii 1891: 33-34; Bin'kovskii 1896: 258], at the spot where they died [Zelenin 1995[1916]: 89], or in swamps [Bin'kovskii 1896: 258]. Tradition prescribed tossing "a bit of straw, a tree branch, or a handful of earth" while passing by the graves of those who died badly and were buried outside of a cemetery [Rudchenko 1874: 71; Chubinskii 1877: 712; Demidovich 1896: 136]. This was believed to bring luck to travellers, or, according to a chumak (barge hauler) saying, "Дорога буде щаслива [The road will be fortunate]" [Rudchenko 1874: 71]. After a time, the accumulated debris at an "unclean" grave was burnt and the fire seen as a "pacifying old sacrifice to [suicides] orphaned and homeless souls" [Kotliarevskii 1891: 34]. Moving the bodies of suicides to another place was taboo because that would be additional desecration of the ground. If absolutely necessary, their bodies could be transferred only over a crossroad, but even then the suicides were believed to return to the old spot of their death over the next seven years. People believed that the sites of death and burial of unclean, unquiet dead were places where evil forces concentrated and that those dead were the source of devilish power. Ukrainians viewed the spirits of suicides as dangerous, since they turned into vampires and the tragic end of their earthly lives caused their souls to hate the living [Sumtsov 1889: 271; Fischer 1921: 361]. The funerals of suicides took place late in the evening and they 
were placed in coffins with their faces down [Lepkyi 1883: 14]. Those who drowned - whether intentionally or accidentally - were interred on the banks of rivers [Demidovich 1896: 137]. It was believed that the unclean forces guarded their sites of drowning and their spirits might appear there [Manzhura 1890: 132].

The "bad" dead had two major reasons for becoming revenants: they lacked proper/complete burials/funerals and they died before their allotted time. Ukrainians used numerous apotropaics, or methods against revenants and turning evil away by mutilation of the corpse was the most common. The aspen is probably the only tree not glorified in Ukrainian folk songs for it was considered a cursed species, the tree on which Judas hanged himself [Bessaraba 1904: 44]. Since people connected the aspen with devilish creatures like witches and the unquiet dead, it was used as a talisman to protect against them [Bin'kovskii 1898: 7]. People would drive an aspen stake through the hearts or heads of such dead to prevent their return. In some regions, people would cut off the head of a suspected witch/wizard and put it in the coffin between the cadaver's legs [Hnatiuk 1904: 165; Zelenin 1995[1916]: 89]. To prevent the unquiet dead from returning and harming the living, people would sow poppy seeds in a circle around their graves or along the way from their former home to their graves; The rationale was that the unquiet dead would compulsively count the tiny poppy seeds and be kept busy all night [Chubinskii 1877: 712; Zelenin 1995[1916]: 53]. Ethnographic descriptions show that although burying suicides and other "bad" dead in regular cemeteries became more widespread by the late nineteenth - early twentieth centuries, their graves could be sealed only after seven years. At times of cataclysms like droughts or epidemics, people would still open such graves and treat the remains cruelly, viewing them as the cause of natural calamities [Bin'kovskii 1898: 8].

Numerous taboos and fears surrounded even the proper funerals of the good dead. Since a body fell into the category of unclean, contaminated, and thus dangerous, many taboos involved the corpse and objects in contact with it. For example, people disposed of "dead water" (water in which a dead body was washed in preparation for the funeral) at a place where no one would walk. Crossing the path of the funeral procession was taboo, for people believed that it would cause inflammation and wounds on the body of that person. Once the coffin had reached the street, survivors shut the gates of the yard, believing that this prevented the deceased from returning to his house from the cemetery [Apollosov 1861: 221]. To defend the living relatives of the 
deceased and to ensure their long life, Ukrainians sprinkled rye inside the house after the deceased was taken outside [ibid.: 221; Miloradovich 1897: 169]. The root of the Ukrainian word жито [rye] is the same as the root of the word життя [life]. People believed in the purifying function of this grain and its ability to revitalize anything contaminated by death [Kotliarevskii 1891: 221]. People believed that the dead had magical power and that physical contact with the body, or coffin, or mere presence at the place of death, would kill developing life, like a fetus or vegetation. Therefore, pregnant women were not to attend funerals, while all seeds and plants were removed from the house where a body lay [Chubinskii 1877: 706]. At the same time, however, a corpse was believed to have healing power over so-called "dead bones," or bone outgrowths/spurs [Vasil'ev 1889: 636; Fischer 1921: 220]. According to the law of imitative magic, materials in contact with a dead body were able to "deaden" pain, feelings, relations, and life itself. For example, washing the mouth with "dead water" supposedly killed a toothache, just as transferring puty from the deceased to the limbs of a sick person would mitigate a toothache or rheumatic pain [Ivanov 1909: 250]. Similarly, it was believed that a kerchief which had closed the jaws of the deceased could stop fights or physical altercations. This would occur if someone had such a kerchief inside his or her pocket and secretly squeezed it [Bin'kovskii 1896: 244]. A rope with which a person committed suicide or a criminal was hanged was highly prized as a way of ensuring good luck or profit and was considered worth stealing and trading [Sumtsov 1889: 256-257].

The corpse itself was believed to be a reliable instrument of prediction: if it was soft when transferred to the coffin, there would soon be another death in the family [Grinchenko 1897: 24]. The eyes of a dead person were covered with coins to prevent him from looking at the living; his stare, it was thought, would cause another death in the family [Chubinskii 1877: 699; Moshkov 1902: 15].

\section{Beliefs Related to Mourning and Commemoration}

Many post-funerary activities were directed towards avoiding things that would make a soul unhappy and doing things that would make it happy. Just as funeral rituals differed depending on the type of death, so there were different ways of memorializing and commemorating the dead. The souls of those who died a good death were prayed for as often as possible. There were twelve special Saturdays throughout the year that 
were variously called поминальні [commemorative], батьківські [parental], or задушні суботи [Saturdays designated for praying for the souls of the dead], and prayers for dead relatives were believed to be especially effective on those days. The prayers of blind minstrels were considered even more beneficial for the souls of the deceased; they were especially powerful if pronounced for those who died a "bad death," since the minstrels were seen as mediators between the world of the living and dead [Kononenko 1998: 189-190].

Ukrainians mourned during the funeral with laments. Sometimes lamenters were professional wailers but most often they were the closest relatives of the deceased. Laments were used to express the grief and pain of loss. They often described the journey of the soul to the other world and villagers believed that laments could facilitate the transfer of a soul to that world. In them, the living expressed concerns that the deceased may suffer from the lack of something. The deceased were asked to visit, asked when they would return, and so on. Thus, laments testify to the folk belief that the dead return for visitations:

\footnotetext{
“Скажи ж мені тепер, коли ж ти до мене в гості прийдеш? Коли ж мені столи застеляти, да коли ж мені тебе ждати? Коли ж ти, моя вірная дружина, в гостоньки прибудеш? Чи на Різдво, чи на Великдень, а чи на зелену неділю?"

"Tell me now when you will come to visit me? When should I set tables and when should I wait for you? When will you, my husband, arrive for a visit? Whether on Christmas or on Easter, or during the week before Pentecost?" [Brailovskii 1884: 183]
}

Again, laments make clear that death was not accepted as the ultimate end of life, but as the beginning of a different reality, analogous to earthly life. They also testify to the belief about uninterrupted contacts between the living and the dead, and the cult of the dead as the protectors of the living.

Loud laments were a sign of a "good funeral" [Bin'kovskii 1896: 251], and people believed that a well lamented soul was happier [Lenchevskii 1899: 77]. While laments provided the opportunity for voluble grief, the community and the closest relatives of the deceased banned extreme expressions of bereavement. It was believed that such displays would be very unpleasant for that soul, since it would not be able to rest, this could possibly bring unwanted reactions from it [Bin'kovskii 1902: 108]. People also believed that too much crying over the deceased would cause her/him to lie in water [Grinchenko 1897: 92]. 
If conventional displays of mourning for the good dead included loud cries and laments, "bad death" was surrounded with silence because it was considered shameful. Nobody wanted to talk about the "bad" dead, so neither psalms nor laments were performed during the funeral. The death and funeral of a small child was also devoid of cries and laments, although the passing was neither terrible nor shameful [Apollosov 1861: 223]. In fact, people believed that small babies and toddlers became angels upon their deaths; they were believed to be taken straight to Heaven by their Heavenly Father [Sventsits'kyi 1912: 27].

Church officials commemorated a deceased person on the third day after death and also on the ninth, and fortieth days. The next major commemoration came one year after death. A sacrificial meal on the commemoration days was seen as necessary for the soul. If the deceased kept returning at night, he was to be asked what his soul needed. He might complain that his soul was hungry. Relatives then were expected to bring commemorative bread to the church for the sake of that soul [Kolessa 1902: 250].

After the commemoration marking one year from the date of death, the deceased attained the status of ancestor, that is they became deindividualized spirits commemorated collectively. Addressing them as “діди [grandparents]" and "батьки [parents]," Ukrainians brought them food, made sacrifices for the sake of their souls (mostly in the form of alms to the poor), asked them for help or advice, and called them out of their graves with prayers and laments [Kotliarevskii 1891: 254].

The souls of unbaptized children, stillborn babies, and those who drowned or died accidentally, were commemorated only once a year on Pentecost [Zelenin 1995[1916]: 234]. There were three special Saturdays throughout October and November designated for remembering the dead. The Sunday after Easter, проводи (hence the etymology - проводжати [to see somebody off]), or St. Thomas's Sunday, was the biggest memorial event, but only for those who had died a good death [Ivanov 1907:107-108]. In some regions of Ukraine, the Thursday before Easter was called мавський/навський Великдень [Easter for the deceased] [Zelenin 1995[1916]: 204, 235]. This was the time that people left bread in rye fields for creatures variously called mavky, navky and rusalky. These were believed to be the unquiet female spirits whose origins will be discussed later.

After the Easter church service, close relatives visited their dead at the cemetery, offered holiday greetings, and buried крашанки, or eggs dyed a single color. The next day, they came to check the eggs: if all 
were intact, it meant the soul of the deceased pleased God; if dogs took any, the soul displeased God and nobody knew how to help it [Ivanov 1907: 96]. People believed that the dead were resurrected on Easter and came invisibly to the church service at midnight and to the homes of their relatives [Hnatiuk 1904: 124]. They were thought to remain in this world until they were commemorated on the Sunday after Easter.

People also believed that souls of those who committed suicide and the souls of witches were lost forever and that there was no way that such souls could be saved. The Church forbade relatives from commemorating the suicides for seven years, which coincided with the period of the ban upon the sealing of the grave [Fischer 1921: 358]. Family ties and pity, however, were often stronger than strict ecclesiastical prohibitions and families of suicides would prepare a "secret Easter" [Miloradovich 1897: $171]$ to remember their unfortunate relatives.

Beliefs about the Afterlife: Perils and the Power of the Soul

The concerns and fears Ukrainians had while dealing with a death were directed toward what would happen to the soul of the deceased and how to please that soul so it would not take revenge on the living. Failure to follow the required funeral formalities could lead to negative consequences for both the living and the dead. Furthermore, folk beliefs about the soul comprised a whole worldview that influenced many other beliefs and often regulated people's daily behavior.

Folk views of the soul were contradictory, probably because it was perceived both as an intangible and as a material entity. Ukrainians imagined the soul as something invisible and light like air and wind. People believed that, at the moment of death, the soul left the body with the final exhalation through the mouth and flew away [Generozov 1883: 6]. At that moment, the soul of a righteous person would take the form of pale smoke [Grinchenko 1897: 66]. Someone's unnatural death, in contrast, was believed to cause atmospheric disturbances such as a strong wind or storm, since the soul of a person who died suddenly or violently had to rush to the other world [Generozov 1883: 6; Fischer 1921: 355].

The soul was also imagined as zoomorphic - in the shape of a butterfly, fly, or bee [Generozov 1883: 10; Moshkov 1902: 15]. This vision of the soul was probably the basis for the custom of leaving something sweet like syta, or kanun (honey dissolved in water) for the soul/fly to drink to fortify itself for the long journey to the other world. On the night after the funeral, old women kept a vigil and looked for the 
soul of the deceased. If it appeared as a fly or butterfly and drank kanun, that meant that the soul was pleased by the funeral and had no anger towards the living.

People imagined that the soul was also able to transform into plants and animals - usually a bird, most often a dove, eagle, or cuckoo [Generozov 1883: 11, 14]. At the same time, people viewed the soul as an anthropomorphic, supernatural entity - a spiritual duplicate of the once living person, one that was able to live its own benevolent or malevolent life. Thus, the soul was believed to survive in the other world with its old earthly habits, needs, mood (attitudes), and human appearance [ibid.: 12]. It needed food and drink, felt cold and heat, suffered, and indulged in pleasures; in other words, the soul behaved much as a living person might.

The living were to protect, help, and please the soul of a dying person. Tolling the church bells was believed both helpful and pleasing to it [Chubinskii 1877: 699]. At the moment of death, body and soul separated, hence, expressions like відійшла душа [the soul has departed] or розлучилася душа з тілом [the soul separated from (its) body]. It was thought that a physical body died, but a soul continued its existence. People believed not as much in the eternity of a soul, but that the soul outlived the body. After soul and body parted, the soul was believed to hover over the body, as if looking for it [Batiushkov 1891: 163]. No matter how bitter that separation, it was important to liberate the soul, and this was the aim of apotropaics used against the unquiet dead.

People believed that a soul could be stolen by evil forces just before the funeral [Fischer 1921: 210]. To prevent this, relatives or neighbors guarded the body during the nights before burial and said prayers. They watched so that a cat or dog would not jump over the dead body, for the soul then would enter the animal's body and not leave the house, making the deceased person into one of the unquiet dead. [Bin'kovskii 1896: 246]. People believed that dogs and cats are associated with the devil and in Ukrainian folklore there are many legends about witches turning into either cats or dogs [Hnatiuk 1912a: 109, 131; Ivanov 1891: 218, 220].

The soul stayed in the house until the body was buried, and it was obligatory for the household to put out a glass of water for drinking and/or bathing and to leave bread for feeding the soul during that time [Kaminskii 1912: 101]. The forty days after burial are called the days of the mytarstva. These are aerial toll houses or spiritual trials which determine whether the soul is righteous or sinful. During this time the soul was believed to visit home daily, where it ate honey to lessen the 
bitterness of its suffering, and rested on a special embroidered towel, rushnyk [Ivanov 1909: 252]. While the deceased was still in the house before burial (and forty days after the funeral), the living were to make sure not to upset the soul. Household tasks like cleaning, washing, whitewashing the walls, or sweeping the floor were taboo, for one could accidentally run into the soul and smear it or cover it with dust. That would make the soul feel unwelcome and cause it to leave the house in anger [Bin'kovskii 1896: 246; Miloradovich 1897: 166; Ivanov 1909: 252].

A human soul after death was believed to be more magically powerful than a living person could ever be. It overcame time and space restrictions, could move about, was able to do things that were beyond human capabilities, acquired different appearances, or took revenge on behalf of a body that was no longer able to act for itself. Even those who disregarded Christian doctrine were scared of the supernatural powers of the soul and the spiritual beings, usually angels, that guided it on its other-worldy journey. A court record from the 1880s shows that murderers who killed and skinned a child for the sake of black magic did not touch the boy's right shoulder and arm because they feared that the child's guardian angel (one is believed to live on each person's right shoulder) would wreak vengeance on them [Lytvyniv 1900: 142].

Souls of those who died in a "bad" way were believed to be able to assist the living, but only those with evil intentions. When a sorcerer wanted to cast a mighty curse, he would go to an aspen tree in the forest and, while facing west, "invoke "those killed, those who had fallen from trees, those who had gone astray, those who had died without names (meaning those who had not been baptised)' to get up" and do harm to a particular person [Mansikka 1909: 9].

Beliefs about the place a soul inhabited were also contradictory. On the one hand, people thought that it stayed in the coffin in the grave, but they also believed it flew away to the other world [Generozov 1883: 20]. Contradictory interpretations of a soul's fate conveyed an archaic view about the multiplicity of souls: one returned to where it originated; another went to the grave with the body; and yet another stayed on earth to protect the living [Ivanov 1909: 248].

Ukrainian laments, burying customs, and commemorative practices are the best testament to folk views on the afterlife. The ideas about the next world were directly related to the nature of death, and people expressed beliefs about this relationship through their rituals. Images of the afterlife are fragmentary, inconsistent, and often illogical, which can 
be explained by a mixture of Christian and folk beliefs [Generozov 1883: 47]. Many apocryphal songs contained detailed descriptions of Heaven and Hell; these were so popular and stable that they found their way into children's folklore. Although mothers forbade their children from imitating funerals or the deceased [Vasil'ev 1890: 321], games called "Heaven" and "Hell" were very common. In them, the players split into two camps - angels and demons. Players competed by dragging members of the other group into their own [Ivanov 1889: 61-63].

Overall, images of the afterlife were expressed in material or concrete terms. People believed that a dead person needed everything there that $\mathrm{s} /$ he had required or failed to achieve in her or his earthly life a family, favorite foods, clothes, and so on. People placed treats into coffins even though the clergy fought this custom as a pre-Christian remnant [Abramov 1907: 29]. Survivors also put the cut nails of the deceased into the coffin so that he could climb a mountain of mytarstva in the other world, pull off worms, or get out of the hellish abyss [Ivanov 1909: 249]. Since Ukrainians attributed to souls relations that replicated those in mortal life, ideas about the other world and the afterlife motivated the attitude of the living towards the dead. People imagined Heaven as a place with a table set with everything the soul had earned in this world, donated to other humans, or sacrificed to God [Manzhura 1890: 155].

Two destinies awaited dead children. In Ukrainian folk beliefs, rusalky and mavky/navky were unquiet spirits of females who died unnaturally, they were thus dangerous to the living, but their origin and functions were viewed differently [Ivanov 1909: 246]. Females who drowned or died during the week preceding Pentecost were believed to become rusalky, while unbaptized girls became mavky regardless of the nature of their death (i.e., they could have been killed by their mothers, were stillborn, or died soon after birth) [Zelenin 1995[1916]: 147]. Mavky were believed to live in forests or mountains, and rusalky in bodies of water. Both rusalky and mavky were dangerous for the living, for they tried to kill humans.

At the same time, there was a belief that unbaptized babies nonetheless ascended to Heaven, although they dwelled separately from baptized children. People also believed that the souls of children had distinctive appearances: the souls of children who were illegitimate, born out of wedlock, or killed upon birth were dirty, while souls of "good" children were white and even had rosy cheeks if a midwife assisted at their deliveries [Ivanov 1909: 246]. 
A different destiny awaited women who died during pregnancy or labor. A pregnant woman who died was to suffer until Judgment Day, while a woman who died in labor or within six weeks after was "considered a martyr and went [directly] to heaven" [Miloradovich 1897: $171]$.

Women who delivered stillborn babies or whose children died did not eat apples till the Ascension Holiday (August $6 / 19$ ). They believed that on that day God gave heavenly apples to children's souls, but only to those whose mothers did not eat them. Otherwise such children were told, “А ваші свині з'їли [And your (apples) have been eaten by pigs]" [Ivanov 1907: 173].

People believed that on Easter and during the preceding week, the gates of Heaven were open to all and mytarstva were eliminated so that souls could ascend directly into Heaven [Bin'kovskii 1896: 259]. People believed that those who died during the first three days of Easter were pure souls, and God granted them his blessing [Ivanov 1907: 93].

Sinners in Hell were thought to sit in craters of boiling tar. Apart from sinners, there were several categories of people who could not enter Heaven due to "shameful" occurrences in their lives: these were bold (maybe self-righteous or overly confident) men [Manzhura 1890: 105], men battered by their wives, and persons attacked by pigs [ibid.: 154].

People believed that the worse a deceased sinner was, the sooner his body would rot. Bodies of vampires, however, did not rot, but were believed to leave their graves at night, walk to homes, and suck blood from the living as they slept. Unclean dead were generally believed to move around. Those who died due to an accident, suicide, or murder were bound to the place of their demise: those who hanged themselves forever returned to the place where they swung, especially during the full moon; those who drowned appeared near that body of water; and those who were murdered went back to the scene of their death [Zelenin 1995[1916]: 48]. Such souls, or rather the evil spirits of such dead, were believed to roam the roads at nights waiting for passersby to kill. And yet the "bad" dead desperately needed the prayers of the living for the peace and salvation of their souls.

\section{Conclusion}

Ukrainian folk beliefs about death and the afterlife at the end of the nineteenth and the beginning of the twentieth century were a synthesis of popular religion and Christian elements. Although death was a natural 
and expected event, folk beliefs about death and the afterlife were characterized by magico-religious syncretism, and the funeral ritual was surrounded by magical prescriptions and taboos. In this way, villagers tried to explain phenomena related to death that were otherwise inconceivable to them.

The world of the dead was a mirror of this world in the Ukrainian folk imagination. It was perceived as a physical reality, with exchanges and transitions between it and the world of the living. Ukrainians did not fear death and kept close relations with their dead, whom they saw as ancestors. What they did fear, however, were the "wrong" things like a "bad" death that resulted in "resurrected" dead. That is why "bad death," unlike good death, was explained by countless beliefs, omens, legends, and tales. The tradition prescribed fear of such unfortunate dead while at the same time a need to pray for the salvation of their souls. Traditional beliefs about death persisted into the twentieth century with few, if any, changes.

\section{NOTES}

1. This article is a revised version of a chapter from my dissertation. In it, I review folk beliefs prevalent at the end of the 19th beginning of the 20th centuries. That was a period of the most intense fieldwork for collecting materials on the Russian Empire, of which Ukraine was a part. Volodymyr Hnatiuk (1904) underlined the importance of collecting folk beliefs about death, soul, afterlife, and various spirits by saying: "[T]his sort of data are of special importance for us, not only because they are scarce but also because they contain many elements that are specific for our folk and, unlike, for example, tales they are not borrowed from any common human source of folklore" (p. i). Most available ethnographic data from that time are about the Ukrainian village beliefs. There is little information about urban beliefs.

\section{BIBLIOGRAPHY}

Abramov, I. 1907. Абрамов, Ив. "Пища покойникам у современных малороссов [Food for the Deceased in Contemporary Ukrainians]," Живая Старина III: 29 (Смесь).

Afanas'ev, А. 1868. Афанасьев, Александр. “Народные суеверия и поверья. Болезни по словянским преданиям [Folk Superstitions 
and Beliefs. Illnesses according to the Slavic Legends]," Филологические Записки IV-V: 335-365.

Apollosov, S. А. 1861. Аполлосов, С.А. "Малороссийские похороны в Подгоренском приходе Острогожского уезда [Ukrainian Funerals in the Podgorensk Parish of Ostrogozh district]," Воронежская Беседа, ст. 218-223.

Bessaraba, I. V. 1904. Бессараба, И. В. “Материалы для этнографии Седлецкой губернии [Ethnographic Materials from the Sedletsk region]," Сборник Отделения русского языка и словесности Императорской Академии Наук LXXV(7): 1-324.

Bin'kovskii, I. 1896. Биньковский, Иван. "Смерть, погребение и загробная жизнь по понятиям и верованию народа [Death, Burial, and Afterlife according to Folk's Views and Beliefs," Киевская Старина LIV: 229-261.

Bin'kovskii, I. 1898. Биньковский, Иван. "Осина в верованиях и понятии народа на Волыни [Aspen in Folk's Beliefs and Views]," Киевская Старина LXI: 6-9 (Документы, известия и заметки).

Bin'kovskii, I. 1902. Биньковский, Иван. “Из области народных верований о выходцах с того света [From Folk's Beliefs about Returning Dead]," Киевская Старина LXXVIII: 108-110.

Brailovskii, S. 1885. Брайловский, С. "Малорусская похоронная причеть и мифическое ее значение [Ukrainian Funerary Laments and Their Mythical Meaning]," Киевская Старина IX: 73-84.

Chubinskii, Р. Р. 1877. Чубинский, П.П. Труды этнографическостатистической экспедиции в западно-русский край. Югозападный отдел. Материаль и исследования. Том 4: Обряды: родины, крестины, свадьба, похоронь [Works of the Ethnographic-Statistical Expedition to the West-Russian Territories. South-West Division. Research Materials. Vol. 4: Rituals: Birth, Baptims, Wedding, and Funerals]. Ст. Петербург: №3 Типография В. Киршбаума.

Demidovich, Р. Р. 1896. Демидович, П.П. "Из области верований и сказаний белорусов [From Beliefs and Legends of Belarusians]," Этнографическое Обозрение I (1); II-III (2-4): 107-145.

Fischer, Adam. 1921. Zwyczaje pogrzebowe ludu polskiego [Funerary Practices of the Polish People]. Lwow: Nakładem zakładu narodowego im. Ossolinskich.

Generozov, Ia. K. 1883. Генерозов, Я. К. Русские народные представления о загробной жизни на основании заплачек, 
причитаний, духовных стихов и m.n. [Russian Folk Views of the Afterlife Based on Laments and Religious Verses]. Саратов.

Grinchenko, D. В. 1897. Гринченко, Д. Б. Этнографические материаль, собранные в Черниговской и соседних с ней губерниях. Выпуск 2: Разсказы, сказки, предания, пословищы, загадки и пр. [Ethnographic Materials Collected in the Chernihiv and Neighboring Regions. Issue 2: Stories, Tales, Legends, Proverbs, Riddles, etc.]. Чернигов: Типография Губернского Земства.

Hnatiuk, V. 1904. Гнатюк, Володимир. “Знадоби до Галицькоруської демонольогіï [Notes on Galician-Rus'ian Demonology]," Етнографічний збірник Наукового Товариства Шевченка Т. $\mathrm{XV}$.

Hnatiuk, V. 1912. Гнатюк, Володимир. “Знадоби до української демонології [Notes on Ukrainian Demonology]," Етнографічий збірник Наукового Товариства Шевченка XXXIII(2).

Ivanov, P. V. 1891. Иванов, П[етро] В. "Народные рассказы о ведьмах и упырях. Материалы для характеристики миросозерцания крестьянского населения Купянского уезда [Folk Tales about Witches and Vampires. Materials Characterizing the Worldview of Peasants of the Kupiansk District]," Сборник Харьковского Историко-филологического Общества III: 156228.

Ivanov, Р. 1907. Иванов, Петр. “Жизнь и поверья крестьян Купянского уезда Харьковской губернии [Life and Beliefs of Peasants of the Kupiansk District of the Kharkiv Region]," Этнографическое Обозрение XVII(1-2): 1-216.

Ivanov, P. V. 1909. Иванов, П[етр] В. “Очерк воззрений крестьянского населения Купянского уезда на душу и на загробную жизнь [A Sketch on Views of Peasant Population of the Kupiansk Region regarding the Soul and Afterlife]," Сборник Харьковского Историко-филологического Общества XVIII: 244-255.

Kaminskii, V. 1912. Каминский, В. “Этнографическое изучение Волыни [Ethnographic Study of the Volyn']," Записки Общества Истории, Филологии и Права при имп. Варшавском ун-те VI: 79-135.

Kolessa, I. 1902. Колесса, Іван. "Галицько-руські народні пісні з мельодіями [Galician-Rus'ian Folk Songs with Melodies]," Етнографічний Збірник Наукового Товариства Шевченка XI. 
Kononenko, Natalie. 1998. Ukrainian Minstrels: And the Blind Shall Sing. Armonk, NY: M.E. Sharpe.

Kotliarevskii, А. 1891. Котляревский, А. "О погребальных обычаях языческих Славян [About Funerary Practices of the Pagan Slavs]" в Сочинения в Сборник отделения русского языка и словесности Императорской Академии Наук XLIX(3): 1-258.

Lenchevskii, L. 1899. Ленчевский, Л. "Похоронные обряды и поверия в Староконстантиновском уезде Волынской губ. [Funerary Rituals and Beliefs in the Starokonstantyniv District of the Volyn' Region]," Киевская Старина LXVI: 70-78.

Lepkyi, D. 1883. Лепкий, Данило. "Похоронні звичаї і обряди у нашого народу [Funerary Rituals and Practices of Our People]", Зоря 1(IV): 13-15.

Liatskii, Е. 1892. Ляцкий, Евг. “Болезнь и смерть по представлениям белоруссов [Illness and Death according to the Views of Belarusians]," Этнографическое Обозрение XIII-XIV(2-3): 2341.

Lytvyniv, A. 1900. Литвинів, А. “Із Глухова (о убійстві, щоб добути людського товщу для злодійської свічки) [From the Hlukhiv Town (About a Murder to Get Lard for a Criminal's Candle]," Земский Сборник Черниговской Губернии I: 136-150.

Mansikka, V. 1909. Мансикка, В. "Представители злого начала в русских заговорах [Representatives of the Evil in Russian Incantations]," Живая Старина IV: 3-30.

Manzhura, I. 1890. Манжура, И[ван Ив.]. “Сказки, пословицы и т.п., записанные в екатеринославской и харьковской губерниях [Tales, Proverbs, etc. Recorded in the Ekaterinoslav and Kharkiv regions]," Сборник Харьковского историко-филологического Общества 2( 2): 1-194.

Moshkov, V. А. 1902. Мошков, В.А. "Гагаузы Бердерского уезда. Этнографические очерки и материалы [The Gagauzs of the Berdery district. Ethnographic sketches and materials]," Этнографическое Обозрение LIV(3): 15-63.

Nomys, М. 1985[1864]. Номис, Матвій. Украӥнські приказки, прислів'я і таке інше [Ukrainian Sayings, Proverbs and the such]. South Bound Brook, NJ: The Publishing Fund of the Ukrainian Orthodox Center.

Rudchenko, I. Ia. 1874. Рудченко, И.Я. Чумацие народые песни [Folk Songs of the Chumaky]. Киев: Типография М.П. Фрица. 
Sumtsov, N. F. 1889. Сумцов, Н.Ф. Культурные переживания [Cultural Experiences]. Киев.

Sventsits'kyi, I. 1912. Свенціцький, Іляріон. "Похоронні голосіння [Funerary Laments]," Етнографічний Збірник Наукового Товариства Шевченка XXXI-XXXII: 1-129.

Svidnyts'kyi, А. 1861. Свідницький, А[натоль]. "Великдень у Подолян [Easter in People of Podillia]," Основа: Южно-русский литер. учен. вестник XI-XII: 26-71.

Vasil'ev, M. К. 1890. Васильев, М.К. "Малорусские похоронные обряды и поверья [Ukrainian Funerary Rituals and Beliefs]," Киевская Старина VIII: 317-322.

Vinogradova, Lyudmila N. 1999. "Notions of "Good" and "Bad" Death in the System of Slavic Beliefs," Etnolog (Slovenski Etnografski muzej) 9(1): 45-49.

Zelenin, D. 1995[1916]. Зеленин, Дмитрий. Избранные труды. Очерки русской мифологии: Умершие неестественной смертью и русалки [Selected Writings. Sketches on Russian Mythology: Those Who Died Unnatural Death and Rusalki]. Москва: Индрик. 